\title{
Vitamin D deficiency in Mexican mothers and their newborns
}

\author{
Erika del Carmen Ochoa-Correa, Pedro Alberto García-Hernández, Jesús Villarreal-Pérez, \\ Consuelo Treviño-Garza, Isaías Rodríguez-Balderrama, Laura Elia Martínez-de Villarreal, \\ Carlos Alberto Zapata-Castilleja and Manuel Enrique De la O-Cavazos \\ Department of Pediatrics, Hospital Universitario Dr. José Eleuterio González, Universidad Autónoma de Nuevo León, Monterrey, Nuevo León, \\ Mexico
}

\begin{abstract}
Objective: The purpose of this study is to establish the prevalence of vitamin D deficiency and their newborns and analyze the risk factors related to this deficiency. Methods: This is an observational, transversal, and prospective study. It included 191 puerperal women and their full-term newborns. Serum 25 hydroxyvitamin $D$ values were analyzes by enzyme immunoassay. Results: $61 \%$ of the puerperal presented deficiency and $26 \%$ insufficiency of vitamin $D$. In the newborn group $98 \%$ showed deficiency and $66 \%$ of them presented severe deficiency. There is a positive correlation between the values of vitamin $D$ in mothers and their newborns ( $r 2=0.173 \mathrm{ng} / \mathrm{ml} ; p=0.017)$. The lowest levels were in autumn. $(15.75 \mathrm{ng} / \mathrm{mL}$ mothers, $6 \mathrm{ng} / \mathrm{mL}$ newborns). There was no correlation between vitamin $D$ levels in mothers and their dietary intake, maternal skin type, sun time exposure and prenatal body mass index. Conclusions: This is the first study that shows the existence of a high deficiency of vitamin $D$ in Mexican mothers and their newborns.
\end{abstract}

KEY WORDS: Vitamin D deficiency. Newborns. Pregnancy. Vitamin D.

\section{Introduction}

Vitamin D deficiency is considered a public health problem world-wide. The relevance of this condition lies in that, in addition to its classical function in bone homeostasis, vitamin $\mathrm{D}$ also intervenes in different biological processes that are important for growth and development both in prenatal and postnatal life ${ }^{1-4}$. There are risk factors that have been associated with this deficiency, such as residing in northern latitudes, limited sun exposure, regular use of sun blockers, dark skin, obesity and malabsorption syndromes ${ }^{1}$. In pregnancy, vitamin $\mathrm{D}$ deficiency is associated with complications such as preeclampsia; in neonates, with low weight and hypocalcemia, as well as poor postnatal growth, bone fragility and increased incidence of autoimmune conditions s $^{1,3,4}$.
There are reports on vitamin $\mathrm{D}$ deficiency in mothers and their newborns in different populations, which is quite variable, even in the same country. In the USA, Mulligan et al. ${ }^{1}$ report a prevalence of this deficiency of $5-50 \%$ in mothers and $54 \%$ in neonates; in turn, Johnson et al. ${ }^{5}$ mention that $30 \%$ of Hispanic pregnant women had vitamin D deficiency. In India, Jain et al. ${ }^{6}$ found vitamin D deficiency in $81 \%$ of women at pregnancy and in $66.7 \%$ of neonates. On the other hand, in countries such as Greece, Belgium and the Netherlands, $10-30 \%$ of women have vitamin $D$ deficiency at pregnancy ${ }^{1,5}$.

Owing to the risk for developing both maternal and fetal problems in the face of a condition of vitamin $D$ deficiency, several countries have implemented supplementation programs during pregnancy and the neonatal period ${ }^{7-9}$. To date, there are no reports in

\author{
Correspondence: \\ M.E. De la O-Cavazos \\ Av. Francisco I. Madero y Gonzalitos, s/n \\ Col. Mitras Centro \\ C.P. 64460 , Monterrey, NL, México \\ E-mail: delaocavazos@yahoo.com
}

Date of reception: 17-01-2017

Date of acceptance: 28-04-2017

DOI://dx.doi.org/10.24875/GMM.M18000043
Gac Med Mex. 2017;153:508-514

Contents available at PubMed www.gacetamedicademexico.com 
Mexico about 25-hydroxy-vitamin D (25OHD) serum concentrations in neonates and their mothers that might lend support to a supplementation policy. The purpose of this investigation is to find out vitamin $D$ values in this population and correlate them with different risk factors that can drive to its deficit.

\section{Methods}

A cross-sectional, prospective observational study was carried out in puerperal women and their neonates at the Hospital Universitario Dr. José Eleuterio González of Monterrey, NL, Mexico. The study population is resident of Monterrey, a city located at $25^{\circ}$ $40^{\prime} 11^{\prime \prime} \mathrm{N}$ latitude, within the period of May 20, 2013 to September 30, 2014. The protocol was authorized by the institution's Research and Ethics Committees (PE13-013). The minors' informed consent was signed by both parents.

The inclusion criteria were: Mexican mothers, of any age, with full-term pregnancy; and full-term (3741 weeks of gestation) and healthy (no complications at birth) neonates. Exclusion criteria were multiple gestation and neonates with major malformations. Censoring criteria were incomplete data or insufficient sample of the mother-child dyad.

In addition to a complete and documented history obtained fom the medical record, all mothers were applied a questionnaire to obtain anthropometric data (prenatal weight and weight at admission for delivery), use of medications and comorbidities. A questionnaire was applied on frequency of vitamin D-containing foods ${ }^{10}$ and consumption of vitamin $D$ supplements, cholecalciferol and ergocalciferol (daily and weekly).

Maternal skin color was evaluated by classifying the phototype according to Fitzpatrick ${ }^{11}$, as well as the time of sun exposure in minutes/day.

The date of birth registry was obtained in the neonates in order to determine the season of the year prevailing at the moment of birth, taking into account the following: spring, from March to May, summer, from June to August, autumn, from September to November, and winter, from December to February; gestational age, which was established using Capurro's method; 1- and 5-minute Apgar; weight in grams; height and head circumference, which was carried out using a measuring rod (SECA 210, Germany), a measuring tape (SECA 201, Germany) and a digital scale (SECA 354, Germany). Anthropometric variables were analyzed with the z-score and percentiles by means of the Fenton chart.
For vitamin D3 quantification, 5-7 $\mathrm{ml}$ of peripheral venous blood were obtained from the mothers' antecubital region within a period of 24 to 48 hours after the obstetric event. In the newborns, a 1-2 $\mathrm{ml}$ capillary blood sample was obtained by puncture (at the moment of the metabolic neonatal screen) at 24-48 hours of extrauterine life. Once the samples were collected, the serum was centrifuged for 20 minutes and stored in aliquots at $-20{ }^{\circ} \mathrm{C}$. All samples were processed at the same time by the enzyme-linked immunosorbent assay (ELISA) method, using a Cobas 6000 Hitachi equipment (Roche, Switzerland). For that purpose, the vitamin D3 ELISA kit Test CEA920Ge 96 (Cloud-Clone Corp. ${ }^{\odot}$, Houston, Tx, USA), the detection range of which is $4.94-400 \mathrm{ng} /$ $\mathrm{mL}$, was used following the provider's specifications. This instrument has a minimum measuring sensitivity of $2.15 \mathrm{ng} / \mathrm{mL}$, high specificity for vitamin D3 detection and an intra-assay precision $\mathrm{CV}<10 \%$ and inter-assay precision $\mathrm{CV}<12 \%$.

250HD serum concentrations for the mother-child dyad were divided using the Society of Clinical Endocrinology ${ }^{12}$ classification, with normal being between 30 and $100 \mathrm{ng} / \mathrm{mL}$, insufficiency with a range of 20 to $29 \mathrm{ng} / \mathrm{mL}$, deficiency between 12 and $19 \mathrm{nh} / \mathrm{mL}$ and serious deficiency $<11 \mathrm{ng} / \mathrm{mL}$.

For statistical analysis, the SPSS 20 pack (IBM, Armonk, NY, USA) was used, with central tendency and dispersion measures being obtained. A p-value < 0.05 was considered to be statistically significant, and Student's t-test was used for independent samples. The Kolmogorov-Smirnov test was used to confirm normal distribution, and the chi-square test was used for categorical variables.

In addition, a univariate Pearson linear correlation test was made between maternal and neonatal vita$\min \mathrm{D}$ values and the neonatal weight variable. Finally, a linear regression multivariate model was used, with $250 H D$ maternal values as dependent variable and vitamin $\mathrm{D}$ consumption in the maternal diet, skin phototype, time of sun exposure and body mass index (BMI) at the start of gestation as covariates.

\section{Results}

A total of 194 mother-child dyads were recruited, out of which three were excluded due to insufficient neonate blood sample, with a total of 191 dyads being left.

Of the mothers, $64 \%$ were adults and $36 \%$ were adolescents; most were homemakers, had basic 
Table 1. Mothers' demographic variables and somatometry, where weight recorded at admission was taken into account for end-of-gestation BMI

\begin{tabular}{|c|c|}
\hline & Total $(n=191)(\%)$ \\
\hline \multicolumn{2}{|l|}{ Age } \\
\hline Adolescents ( $\leq 19$ years) & $69(36)$ \\
\hline Adults ( $\geq 20$ years) & $122(64)$ \\
\hline \multicolumn{2}{|l|}{ Occupation } \\
\hline Homemaker & $169(88)$ \\
\hline Student & $9(5)$ \\
\hline Employee & $13(7)$ \\
\hline \multicolumn{2}{|l|}{ Marital status } \\
\hline Single & $32(17)$ \\
\hline Married & $48(25)$ \\
\hline Cohabitating & $104(55)$ \\
\hline Divorced & $2(1)$ \\
\hline \multicolumn{2}{|l|}{ Education } \\
\hline Illiterate & $2(1)$ \\
\hline Primary school & $34(18)$ \\
\hline Secondary school & $87(46)$ \\
\hline High school & $61(32)$ \\
\hline College degree & $4(2)$ \\
\hline Weight at pregnancy initiation $(\mathrm{kg})$ & $60,39 \pm 13,44$ \\
\hline Prenatal BMI & $24,31 \pm 5,08$ \\
\hline Normal $(<25)$ & $122(64)$ \\
\hline Overweight (25-29.99) & $40(21)$ \\
\hline Obesity $(>30)$ & $29(15)$ \\
\hline $\begin{array}{l}\text { Weight at pregnancy } \\
\text { conclusion }(\mathrm{kg})\end{array}$ & $72,84 \pm 13,87$ \\
\hline BMI at pregnancy conclusion & $29,35 \pm 5,34$ \\
\hline Normal $(<25)$ & $42(22)$ \\
\hline Overweight (25-29.99) & $76(40)$ \\
\hline Obesity $(>30)$ & $73(38)$ \\
\hline Previous gestations & $74(39)$ \\
\hline 0 & $59(31)$ \\
\hline 1 & $33(17)$ \\
\hline 2 & $25(13)$ \\
\hline $3+$ & \\
\hline
\end{tabular}

education and a stable partner. When maternal anthropometric variables were measured, one third of participants were observed to have initiated pregnancy with overweight or obesity, and at the end of it, this figure increased to $78 \%$ (Table 1). In turn, neonatal anthropometric measures were within normal percentiles (Table 2).

Mean $25 \mathrm{OHG}$ was $19.74 \pm 10.21 \mathrm{ng} / \mathrm{mL}$ in the mothers and $9.42 \pm 3.53 \mathrm{ng} / \mathrm{mL}$ in the neonates. This reveals that only $13 \%$ of mothers had normal values (> $32 \mathrm{ng} / \mathrm{mL}$ ), whereas $26 \%$ showed insufficiency (20$31 \mathrm{ng} / \mathrm{mL}$ ) and $61 \%$ had deficiency $(<20 \mathrm{ng} / \mathrm{mL})$. More relevant yet is the fact that all neonates had abnormally low $250 \mathrm{HD}$ values: $2 \%$ had insufficiency and
Table 2. Neonatal variables

\begin{tabular}{lc}
\hline & Total $(\mathbf{n}=\mathbf{1 9 1})(\%)$ \\
\hline $\begin{array}{l}\text { Type of delivery } \\
\text { Vaginal delivery }\end{array}$ & $113(59)$ \\
Cesarean section & $78(41)$ \\
Gender & \\
Male & $95(49)$ \\
Female & $96(51)$ \\
Apgar & Mean (SD) \\
1-minute & $8( \pm 0,60)$ \\
5-minute & $9( \pm 0,80)$ \\
Gestational age & $39,1( \pm 1,19)$ \\
Weight (g) & $3254,71( \pm 411,32)$ \\
Z-score & $-0,15( \pm 0,85)$ \\
Height (cm) & $50,33( \pm 1,81)$ \\
Head & $34,30( \pm 1,50)$ \\
circumference $(\mathrm{cm})$ & \\
\hline SD: standard deviation &
\end{tabular}

$98 \%$ had deficiency. Of the latter, $66 \%$ had severe deficiency, defined by values $<11 \mathrm{ng} / \mathrm{mL}$.

On the other hand, there is a weak positive correlation between $25 \mathrm{OHD}$ values of the mother and neonates 25OHD serum concentrations $\left(r^{2}=0.173\right.$; $p=0.017)$. In addition, maternal 25OHD serum concentrations predict neonatal $250 \mathrm{HD}$ values $\left(r^{2}=0.030\right.$; $p=0.017)$.

Following the previously-used classification, where the sample was divided into groups of adolescent mothers and adult mothers, no statistically significant differences were found in 25OHD serum values between both groups, as well as neither were found in the neonates (Table 3).

Mothers' daily average time of sun exposure during pregnancy was $85 \pm 91.06$ minutes (range: 5-600). Vitamin D daily consumption through the diet was 172 $\pm 76.31 \mathrm{IU}$ on average (range: 14-341). Only 52 mothers $(27.22 \%)$ received vitamin D supplementation, with a mean of $291 \pm 76.44$ IU/day (range: 171-500) (Table 4); however, no differences were found between the mothers who consumed supplements and those who didn't.

The predominant maternal skin phototype was $3(40.31 \%)$, followed by phototypes 4,5 and 2 . There were no phototypes 1 and 6 . When 25OHD means were compared according to the phototype, no statistically significant difference was found $(p=0.62)$.

Figure 1 shows mothers and newborns mean $250 H D$ serum values by season of the year at the 
Table 3. Comparison of maternal and neonatal serum 25-hydroxyvitamin D according to maternal age

\begin{tabular}{lccc}
\hline Classification & Total $(\mathbf{n}=\mathbf{1 9 1})(\%)$ & Adolescent mothers $(\mathbf{n}=\mathbf{6 9})(\%)$ & Adult mothers $(\mathbf{n}=\mathbf{1 2 2})(\%)$ \\
\hline Maternal & & & $\mathbf{p}$ \\
$\quad$ Normal $(32-100 \mathrm{ng} / \mathrm{mL})$ & $26(13)$ & $9(13)$ & $17(14)$ \\
Insufficiency $(20-31 \mathrm{ng} / \mathrm{mL})$ & $49(26)$ & $18(26)$ & $31(25)$ \\
Deficiency $(12-19 \mathrm{ng} / \mathrm{mL})$ & $95(50)$ & $35(51)$ & $60(49)$ \\
Severe deficiency $(<11 \mathrm{ng} / \mathrm{mL})$ & $21(11)$ & $7(10)$ & $14(12)$ \\
Neonatal & & & 0.98 \\
$\quad$ Normal $(32-100 \mathrm{ng} / \mathrm{mL})$ & 0 & 0 & $2(2)$ \\
Insufficiency $(20-31 \mathrm{ng} / \mathrm{mL})$ & $3(2)$ & $1(1)$ & $39(32)$ \\
Deficiency $(12-19 \mathrm{ng} / \mathrm{mL})$ & $62(32)$ & $23(33)$ & $81(66)$ \\
Severe deficiency $(<11 \mathrm{ng} / \mathrm{mL})$ & $126(66)$ & $45(65)$ & 0.3 \\
\hline
\end{tabular}

Table 4. Dietary and supplementary vitamin D consumption

\begin{tabular}{lccc}
\hline Oral consumption & $\begin{array}{c}\text { Total } \\
\mathbf{n}=\mathbf{1 9 1}\end{array}$ & Mean \pm SD & Range \\
\hline Diet (IU/day) & 191 & $172 \pm 76,31$ & $14-341$ \\
Supplement (IU/day) & 52 & $291 \pm 76,44$ & $171-500$ \\
Diet+supplement (IU/day) & 52 & $462 \pm 105,49$ & $239-676$ \\
\hline
\end{tabular}

SD: standard deviation

moment of birth. The lowest values were found in autumn.

In the multivariate correlation, no association was found of maternal $250 \mathrm{HD}$ values with vitamin $D$ dietary consumption $\left(r^{2}=-0.10 ; p=0.79\right)$ or with maternal skin phototype $\left(r^{2}=-0.019 ; p=0.79\right)$, time of sun exposure $\left(r^{2}=-0.44 ; p=0.54\right)$, BMI at the end of pregnancy $\left(r^{2}=-0.124 ; p=0.08\right)$ or season of year $\left(r^{2}=0.033 ; p=0.65\right)$.

\section{Discussion}

Vitamin $D$ is the main hormone in phosphocalcic metabolism regulation. Its deficiency is a health problem all over the world ${ }^{1-3,7,13}$ and there are diseases at pediatric age that involve alterations in vitamin $D$ metabolism, such as rickets, chronic renal failure, allergic conditions, cancer, pathologies associated with fat malabsorption (cystic fibrosis, celiac disease), obesity and overweight ${ }^{7,12,14}$. Currently, populations with high deficiency of this vitamin have been described in all continents, including Spanish-speaking countries such as Spain and Argentina ${ }^{15,16}$.

Specifically in newborns, the vitamin $D$ reserve depends on maternal transference via the placenta. After birth, this supply depends on the newborn's own production and exogenous supply'. In pregnancy, vitamin $D$ deficiency is associated with severe preeclampsia and in the neonate with hypocalcemia, rickets (especially in premature children) ${ }^{14}$ and low weight for gestational age 1 . Vitamin D optimal values during pregnancy and at neonatal stage still remain controversial. There are the Institute of Medicine and the Society of Clinical Endocrinology classifications ${ }^{12}$, with the latter being the one that was used in the present work, which establishes normality values ranging from 32 to $100 \mathrm{ng} / \mathrm{mL}$, insufficiency ranging from 20 to $31 \mathrm{ng} / \mathrm{mL}$, deficiency ranging from 12 to $19 \mathrm{ng} / \mathrm{mL}$ and severe deficiency at $<11 \mathrm{ng} / \mathrm{mL}$. This classification is currently the most widely used and it has shown that insufficiency values are associated with extra-skeletal alterations.

This report revealed that $61 \%$ of mothers and $98 \%$ of neonates had values indicating 25OHD deficiency. These results are consistent with international investigations that confirm that vitamin $\mathrm{D}$ deficiency is highly prevalent among pregnant women and their newborns $^{16-20}$. On the other hand, there was a weakly positive correlation observed between maternal and neonatal 25OHD values $\left(r^{2}=0.173 ; p=0.017\right)$. This correlation was similar to that reported by Abbasian et al. ${ }^{13}$ for maternal serum and umbilical cord $250 \mathrm{HD}$ values in an Iranian population $\left(r^{2}=0.12 ; p=0.053\right)$.

In our country, there are reports with regard to vitamin $D$ blood values in different age groups. In the National Health Survey ${ }^{21}, 9.8 \%$ of adults were reported to have $250 H D$ deficiency, $20 \%$ had insufficiency, and approximately $70 \%$ had sufficiency, whereas Elizondo et al. ${ }^{22}$ analyzed 6-12-year obese pediatric patients from the same region of our study, and found that they had deficiency at a similar proportion to that found in mothers in the present work. No reports analyzing vitamin $D$ values in the mother-child dyad were found, in addition to this being the first study in Mexican newborns.

In the present investigation, no differences were found between adolescent mothers and adult mothers blood values. This differs from reports in the literature 


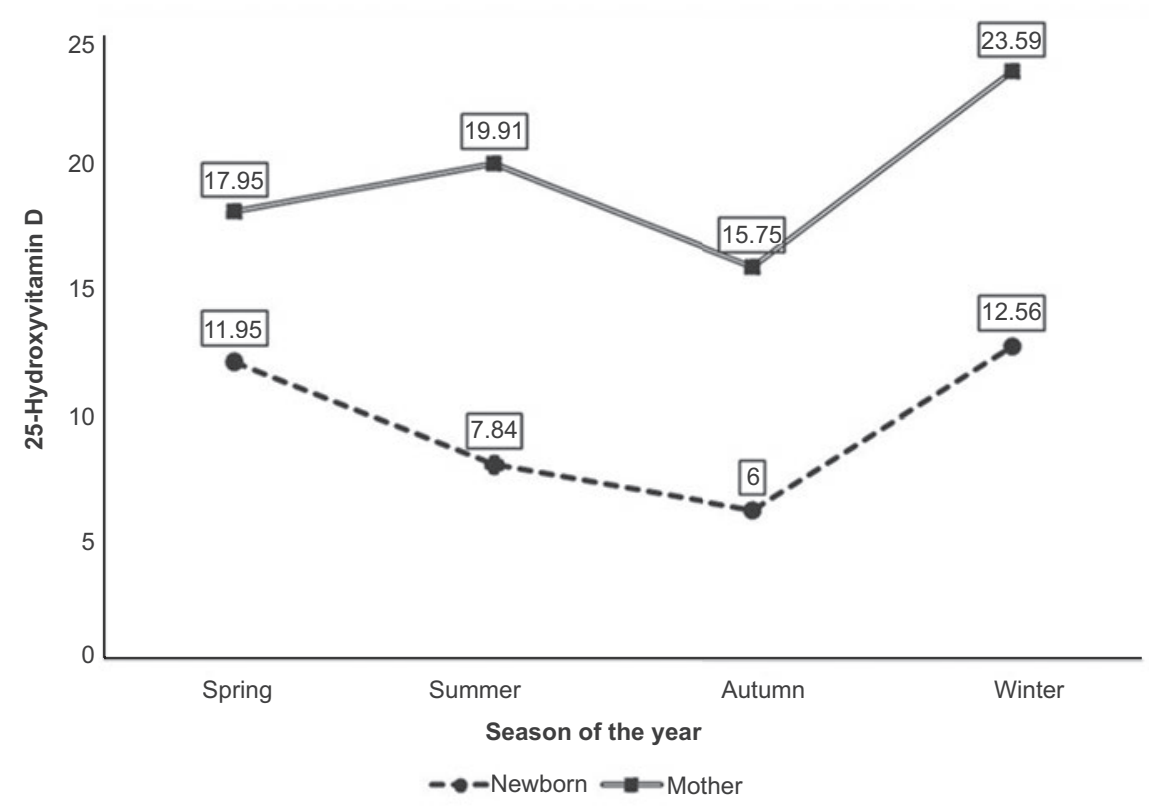

Figure 1. 25-hydroxyvitamin D average values in mothers and newborns according to the season of the year. Seasonal variability is evidenced, with the lowest values being found in autumn.

on other population groups, where adolescent mothers have higher bone mass loss since the beginning of pregnancy until the sixth week postpartum, indicating that the prevalence of vitamin D deficiency in them is higher ${ }^{13,23-25}$.

Our study documented that one third of the mothers had overweight or obesity at the beginning of pregnancy, which was significantly increased at its conclusion. Although no correlation was found between maternal BMI at the end of pregnancy and 25OHD values, vitamin $\mathrm{D}$ deficiency has been reported to likely be associated with obesity, and two mechanisms have therefore been proposed: 1) excessive body fat sequesters circulating vitamin $D, 2$ ) vitamin $D$ deficiency increases fat accumulation in the body $26-29,3)$ the overweight/obesity and insulin resistance association $^{29}$. Elizondo et al. ${ }^{22}$ demonstrated that there was higher prevalence of $250 \mathrm{HD}$ deficiency in a group of obese subjects in comparison with a control group of non-obese subjects, but no significant correlation was found between $250 \mathrm{HD}$ levels and maternal BMI at the end of pregnancy in their study. One weakness of the present study is that $250 \mathrm{HD}$ values were not analyzed at the beginning of pregnancy, and their correlation with $\mathrm{BMI}$ at the beginning of pregnancy could therefore not be analyzed.

It is important for the skin phototype to be considered, since the concentration of melanin regulates the amount of UVB radiation that penetrates until reaching epidermal layers with maximum 7-dehydrocholesterol concentration $^{30,31}$. Skin phototype, defined as the sun adaptation capability each person has, is classified in six categories according to Fitzpatrick, which range from phototype 1, corresponding to individuals with white skin and red hair, to phototype 6 for people with dark skin and black hair ${ }^{11,32}$.

The predominating maternal skin phototype was 3 . When the means were compared by phototype, no statistically significant difference was observed. These results are different to reports in the international literature, where vitamin $D$ values are claimed to be inversely associated with the maternal skin phototype, in such a way that the higher it is, the higner the risk for avitaminosis can be 11,32-34. $^{10}$

Another aspect to be highlighted is that, in spite of the fact that the latitude the city of Monterrey is located in ( $\left.25^{\circ} 40^{\prime} 11^{\prime \prime} \mathrm{N}\right)$ has abundant solar radiation, no statistically significant difference was detected in the comparison of $25 \mathrm{OHD}$ mean values by time solar of exposure, although we did find a highly important variation between participants. These findings are consistent with those in other populations with high solar exposure, at latitudes that are similar to ours. Such is the case of the Mediterranean region, India and Tunisia ${ }^{6,35,36}$.

When the 250HD values and the season of the year at the moment of the obstetric event were analyzed, no correlation was found; furthermore, the lowest 
values were in autumn, which is different to observations reported in the literature, where vitamin D lowest values occur in the winter season and early spring ${ }^{6,33}$. A hypothesis would be that the geographic region where the study took place, although with a predominantly dry and semi-dry climate, has a mean yearly precipitation of $650 \mathrm{~mm}$, and rains occur in the months of August and September ${ }^{37}$; therefore, solar exposure is decreased in these months, and since vitamin $D$ synthesis develops in approximately 3 weeks, this might explain the detection of the lowest $250 \mathrm{HD}$ values at the beginning of this season of the year.

The main vitamin $D$ exogenous input is provided by ergocalciferol $\left(D_{2}\right)$ through the diet and cholecalciferol $\left(D_{3}\right)^{38}$. Dietary vitamin $D$ daily consumption was considered in the study participants. It was low, similar to what Ortigosa et al. ${ }^{39}$ reported in a sample that included South American women living in Barcelona, Spain. This result may be secondary to the fact that they are native to South America and they continue with alimentary habits and costumes that are similar to those of their place of origin.

Finally, it was demonstrated that only $27 \%$ of mothers consumed vitamin D supplements during gestation. This was at doses ranging from 171 to $500 \mathrm{lU} /$ day, which are much lower amounts than those internationally recommended of $600-4000 \mathrm{IU} / \mathrm{day}^{40}$. This is due to the fact that in Mexico there is no policy for vitamin D supplementation during pregnancy and, therefore, the amount of it multivitamin supplements prescribed during pregnancy should contain is not regulated. In Mexico, vitamin D deficiency is regarded as a rare pathology ${ }^{14}$, especially owing to the lack of scientific evidence, since there are very few prevalence studies and, currently, none has included both puerperal women and their newborns. The results obtained in the present investigation document that there is a high prevalence of vitamin $D$ deficiency at birth, although immediate complications in newborns could not be evinced. However, this does not exclude the possibility of long-term hypovitaminosis D-related complications. Maternal milk has been shown to contain very low amounts of vitamin D (25-78 IU/L), and an exclusively breastfed infant has a higher predisposition to have vitamin $D$ deficiency ${ }^{41}$. Therefore, it is suggested that vitamin $D$ deficiency should be considered a public health problem and that supplementation actions should be carried out, both at pregnancy and neonatal stage, by increasing the doses recommended by the Mexican Official Standard NOM-051SCFI/SSA1-2010, which suggests a daily intake of
$224 \mathrm{IU}$, based on recommendations of the Instituto Nacional de Ciencias Médicas y Nutrición Salvador Zubirán ${ }^{14}$.

Performing prospective studies in Mexico is recommended, using different supplementation doses between 400 and $1000 \mathrm{IU} /$ day in neonates and infants, including the different types of nutrition as variables, in order to establish an optimal dose in this population group.

\section{Conclusions}

There is a high prevalence of vitamin $D$ deficiency in mothers and their newborns, regardless of factors such as maternal age, weight, time of solar exposure, latitude of place of residence, season of the year and skin phototype.

For future investigations, carrying out a larger population-based study, analyzing vitamin D-receptor gene most common polymorphisms and using different vitamin $D$ supplementation schemes would be convenient.

\section{Financial resources}

This study was carried out with Universidad Autónoma de Nuevo León Hospital Universitario Dr. José Eleuterio González Pediatrics and Endocrinology Departments own resources. The authors declare there are no external financing sources to declare.

\section{Acknowledgements}

To Laura Jaqueline Cortés Gallardo, BSc in Clinical Biochemistry, Gloria Alejandra Jasso de la Peña, MBA, Brenda Leticia Méndez Guerrero, MD, and Neri Alejandro Álvarez Villalobos, MD, for their valuable collaboration.

\section{References}

1. Mulligan ML, Felton SK, Riek AE, et al. Implications of vitamin D deficiency in pregnancy and lactation. Am J Obstet Gynecol. 2010;202:429. e1-9.

2. Bischoff-Ferrari H. Vitamin D - Role in pregnancy and early childhood. Ann Nutr Metab. 2011;59:17-21.

3. Holik MF. Vitamin D deficiency. N Engl J Med. 2007;357:266-81.

4. Bodnar LM, Catov JM, Simhan HN, et al. Maternal vitamin D deficiency increases the risk of preeclampsia. J Clin Endocrinol Metab. 2007;92:3517-22.

5. Johnson DD, Wagner CL, Hulsey TC, et al. Vitamin D deficiency and insufficiency is common during pregnancy. Am J Perinatol. 2011;28:7-12.

6. Jain V, Gupta N, Kalaivani M, et al. Vitamin D deficiency in healthy breastfed term infants at 3 months and their mothers in India seasonal variation \& determinants. Indian J Med Res. 2011;133:267-73.

7. Saggese G, Vierucci F, Boot AM, et al. Vitamin D in childhood and adolescence: an expert position statement. Eur J Pediatr. 2015;174:565-76. 
8. Canadian Paediatric Society. Vitamin D supplementation: recommendations for Canadian mothers and infants. Paediatr Child Health. 2007; 12:583-9.

9. American College of Obstetricians and Gynecologists. Vitamin D screening and supplementation during pregnancy. Committee Opinion No. 495. Obstet Gynecol. 2011;118:197-8

10. Taylor C, Lamparello B, Kruczek K, et al. Validation of a food frequency questionnaire for calcium and vitamin $\mathrm{D}$ intake in adolescent girls with anorexia nervosa. J Am Diet Assoc. 2009;109:479-85.

11. Freedberg IM, Eisen $A Z$, Wolff $K$, et al., editores. Fitzpatrick's Dermatology in general medicine. 6th ed. New York McGraw-Hill; 2003.

12. Holick MF, Binkley NC, Bischoff-Ferrari HA, et al. Evaluation, treatment, and prevention of vitamin $D$ deficiency an Endocrine Society Clinical Practice Guideline. J Clin Endocrinol Metab. 2011;96:1911-30.

13. Abbasian $\mathrm{M}$, Chaman $\mathrm{R}$, Amiri $\mathrm{M}$, et al. Vitamin $\mathrm{D}$ deficiency in pregnant women and their neonates. Glob J Healt Sci. 2016;8:83-90.

14. López-González D, Méndez-Sánchez L, Guagnelli MA, et al. Deficiencia de vitamina $D$ en la edad pediátrica. Una oportunidad de prevención. Boletín Médico del Hospital Infantil de México. 2015;72:225-34.

15. Sánchez Muro JM, Yeste Fernández D, Marín Muñoz A, et al. Niveles plasmáticos de vitamina $\mathrm{D}$ en población autóctona y en poblaciones inmigrantes de diferentes etnias menores de 6 años de edad. An Pediatr (Barc). 2015;82:316-24.

16. Sánchez $A$. Vitamina $D$ en el embarazo: su importancia para la madre y el feto. Actual Osteol. 2014;10:265-9.

17. Dror DK, King JC, Fung EB, et al. Evidence of associations between feto-maternal vitamin $D$ status, cord parathyroid hormone and bone-specific alkaline phosphatase, and newborn whole body bone mineral content. Nutrients. 2012:4:68-77.

18. Marshall I, Mehta R, Petrova A. Vitamin D in the maternal-fetal-neonatal interface clinical implications and requirements for supplementation. J Matern Fetal Neonatal Med. 2013;26:633-8.

19. Dawodu A, Wagner CL. Mother-child vitamin D deficiency an international perspective. Arch Dis Child. 2007;92:737-40.

20. Sánchez A. Vitamina D actualización. Rev Med Rosario. 2010;76:70-82.

21. Flores M, Sánchez-Romero LM, Macías N, et al. Concentraciones séricas de vitamina $D$ en niños, adolescentes y adultos mexicanos. Resultados de la ENSANUT 2006. México Instituto Nacional de Salud Pública 2006. p. 15-26.

22. Elizondo-Montemayor L, Ugalde-Casas PA, Serrano-González M, et al. Serum 25-hydroxyvitamin D concentration, life factors and obesity in Mexican children. Obesity. 2010;18:1805-11.

23. Chan GM, McElligott $K$, McNaught $T$, et al. Effects of dietary calcium intervention on adolescent mothers and newborns. Obstet Gynecol. 2006;108:565-71.

24. Diogenes ME, Bezerra FF, Rezende EP, et al. Effect of calcium plus vitamin $D$ supplementation during pregnancy in Brazilian adolescent mothers a randomized, placebo-controlled trial. Am J Clin Nutr. 2013;98:82-91

25. Young BE, McNanley TJ, Cooper EM, et al. Vitamin D insufficiency is prevalent and vitamin $\mathrm{D}$ is inversely associated with parathyroid hormone and calcitriol in pregnant adolescents. J Bone Miner Res. 2012;27:177-86.
26. Soares MJ, Chan She Ping-Delfos W, Ghanbari MH. Calcium and vitamin $\mathrm{D}$ for obesity a review of randomized controlled trials. Eur $\mathrm{J}$ Clin Nutr. 2011;65:994-1004

27. Awad AB, Alappat L, Valerio M. Vitamin D and metabolic syndrome risk factors evidence and mechanisms. Crit Rev Food Sci Nutr. 2012; 52:103-12.

28. Masvidal Aliberch RM, Ortigosa Gómez S, Baraza Mendoza MC, et al. Vitamina D: fisiopatología y aplicabilidad clínica en pediatría. An Pediatr (Barc). 2012;77:279.e1-10.

29. Loya-López GM, Godínez-Gutiérrez SA, Chiquete E, et al. Niveles de vitamina $D$ en pacientes con sobrepeso y obesidad y su asociación con resistencia a la insulina. Revista de Endocrinología y Nutrición. 2011;19:140-5.

30. Misra M, Pacaud D, Petryk A, et al. Vitamin D deficiency in children and its management review of current knowledge and recommendations. Pediatrics. 2008;122:398.

31. Holick MF. Sunlight and vitamin D for bone health and prevention of autoimmune diseases, cancers, and cardiovascular disease. Am J Clin Nutr. 2004;80(6 Suppl):1678S-88S

32. Togo A, Espadas M, Blanes Segura S, et al. ¿Existe déficit de vitamina D en los niños de una ciudad soleada del Mediterráneo? An Pediatr (Barc). 2016;84:163-9.

33. Bonilla $C$, Ness AR, Wills AK, et al Skin pigmentation, sun exposure and vitamin D levels in children of the Avon Longitudinal Study of Parents and Children. BMC Public Health. 2014;14:597.

34. Bodnar LM, Simhan HN, Powers RW, et al. High prevalence of vitamin $D$ insufficiency in black and white pregnant women residing in the northern United States and their neonates. J Nutr. 2007; 137:447-52.

35. Karras S, Paschou SA, Kandaraki E, et al. Hypovitaminosis D in pregnancy in the Mediterranean region a systematic review. Eur J Clin Nutr. 2016;70:979-86

36. Ayadia ID, Nouailia EB, Talbi E, et al. Prevalence of vitamin D deficiency in mothers and their newborns in a Tunisian population. Int J Gynaecol Obstet. 2016;133:192-5.

37. Instituto Nacional de Estadística, Geografía e Informática (INEGI). Prontuario de información geográfica municipal de los Estados Unidos Mexicanos. Monterrey, Nuevo León. Disponible en http//www3.inegi.org.mx/ sistemas/mexicocifras/datos-geograficos/19/19039.pdf

38. Urrutia-Pereira M, Solé D. Vitamin D deficiency in pregnancy and its impact on the fetus, the newborn and in childhood. Rev Paul Pediatr. 2015;33:104-13

39. Ortigosa Gómez S, García-Algar O, Mur Sierra A, et al. Concentraciones plasmáticas de $25-\mathrm{OH}$ vitamina $\mathrm{D}$ y parathormona en sangre de cordón umbilical. Rev Esp Salud Pública. 2015;89:75-83.

40. Aghajafari F, Field CJ, Kaplan BJ, et al. The current recommended Vitamin $D$ intake guideline for diet and supplements during pregnancy is not adequate to achieve vitamin D sufficiency for most pregnant women. PLoS One. 2016;11:e0157262.

41. Wagner CL, Greer FR. American Academy of Pediatrics Section on Breastfeeding; American Academy of Pediatrics Committee on Nutrition. Prevention of rickets and vitamin D deficiency in infants, children, and adolescents. Pediatrics. 2008;122:1142-52. 